\title{
LATEGLACIAL STUDIES IN THE WESTERN VALLEYS OF THE ITALIAN JULIAN ALPS AND IN THE KORITNICA VALLEY
}

Wolfgang Tintor, Maja Andrič

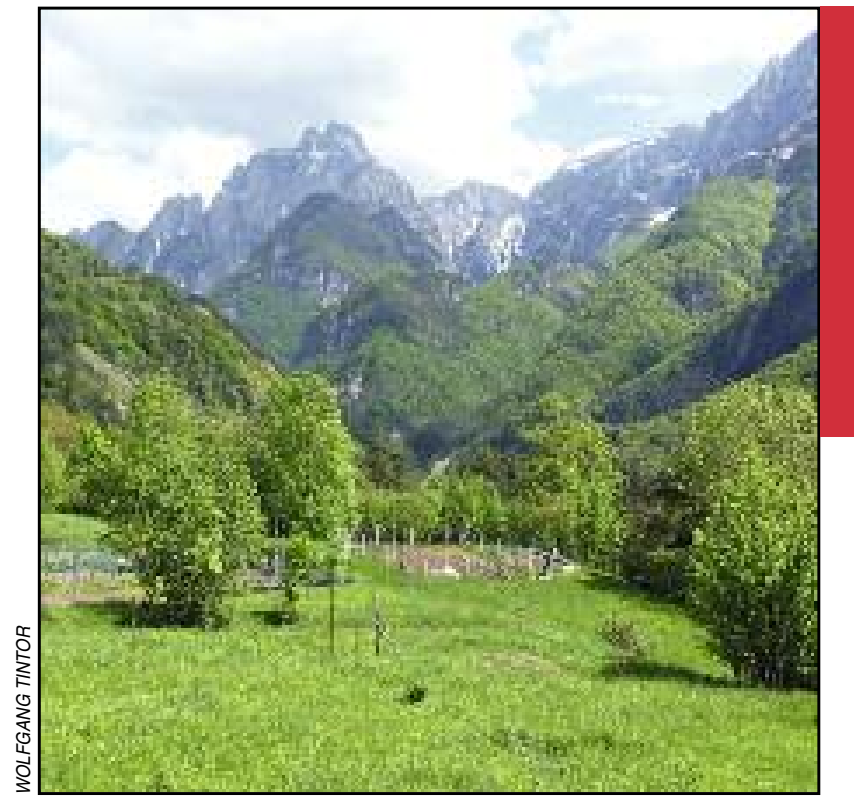

Dogna valley with Montasio, Jof di Miez and Monte Zabus. Positon Chiout di Gus. 


\title{
Lateglacial studies in the western valleys of the Italian Julian Alps and in the Koritnica valley
}

DOI: http://dx.doi.org/10.3986/AGS54101

UDC: $911.2: 551.435 .4(234.323 .6)$

COBISS: 1.01

\begin{abstract}
Different from the northern valleys of the Italian Julian Alps the bottoms of the western valleys do not contain any late-pleistocene moraines. However, common to all valleys is the large glaciation most probably in the Gschnitz-stage, in which the glaciers reached particularly low locations due to special favourable aspects such as north-exposure, steep and narrow gorges, high shading and considerable snow accumulation. This is also valid for the sidebranches of the Slovenian Koritnica valley which are again directed west-east. Still younger glacier stages could be found in the upper sections of the Dogna, Raccolana and Bala valley. For the moraines of very low altitudes in the Resia valley, at the entrance to Možnica and the upper Raccolana valley pollen analyses are available. All considerations in the paper are estimations based on geomorphological and climatological experience.
\end{abstract}

KEY WORDS: geomorphology, glacial, Gschnitz stadial, gorge-like valleys, high precipitation, moraines, kame terraces, pollen analysis

The article was submitted for publication on May 26, 2010.

ADDRESSES:

Wolfgang Tintor, Ph. D.

Korpitsch 26, A - 9587 Riegersdorf, Austria

E-mail: wolfgang.tintor@aon.at

Maja Andrič, Ph. D.

Institute of Archaeology

Scientific Research Centre of the Slovenian Academy of Sciences and Arts

Novi trg 2, SI - 1001 Ljubljana, Slovenia

E-mail: maja.andric@zrc-sazu.si 


\section{Introduction}

\subsection{General facts concerning the Lateglacial}

After the rapid decay of the high-glacial ice stream-net and the piedmont lobes about 21,000-19,000 years ago a transitional era followed with several halts and readvances which were named the »Alpine Lateglacial « by Penck and Brückner (1901/1909). Large parts of the Central Alps were deglaciated, even if still big systems of dendritic glaciers existed which filled especially the longitudinal valleys of the Inn or Drau (van Husen 2000). The oldest stadials were named after the classical type localities »Bühl « and »Steinach» (Heuberger 1968); in the latter stage the main valleys were already free of ice and the glaciers had retreated into the tributary valleys (van Husen 2000). After a marked cooling phase the »Gschnitz« readvance occurred with large blocky ridges (Ivy-Ochs et al. 2005). With well-defined, often sediment-rich moraines from cirque and smaller valley glaciers the "Senders « stadial followed with its type locality being situated in the rear part of the Stubai valley (Kerschner 1986). Likewise in the Stubai valley both of the youngest readvance phases, „Daun« and »Egesen « were discovered with little accentuated moraines showing solifluction overprint for the older phase.

However, the Egesen stage contains sharp-crested, often blocky ridges mostly at the foot of cirques (Ivy-Ochs et al. 2005). With the exception of the Egesen readvance which was dated in the Younger Dryas $(11,000-10,000 \mathrm{BP})$ the absolute ages of the individual stadials are still unclear; according to a recent paper the Gschnitz stadial can be classified to $15,400 \pm 1400$ BP (Ivy-Ochs et al. 2005).

Regarding the temperature conditions in the Bühl and Steinach stage little more is known than estimated values; for the Gschnitz stadial, however a lowering of the summer temperatures was calculated with $8.5-10.0^{\circ}$, whereas for the Younger Dryas they were only $3.5-4.0^{\circ} \mathrm{C}$ lower than modern values (Ivy-Ochs et al. 2005).

Considering the more maritime external areas of the Alps, to which the Julian Alps are counted, the lowering of the mean annual air temperature in the Tyrolean Alps was calculated with $4.1^{\circ}$ for the Senders stadial, with $3.5^{\circ}$ for the Daun stadial and with $2.9^{\circ}$ for the Egesen stadial (Kerschner 1985). Different from the still drier Central Alps in the Lateglacial the more oceanic Southern Alps received about the same amounts of precipitation as today (Kerschner 1985).

The impact of two of the coldest stadials - Gschnitz and Egesen - also affected the vegetation composition: with climatic warming after the Gschnitz stadial afforestation progressed and the treeline in northern Italy shifted to $800-1000 \mathrm{~m}$ (Vescovi 2007). This trend even increased at ca. 14,800-14,400 and 13,800 cal. BP with a change in forest composition and density having more broadleaved trees. The results of the vegetation: the landscape in the Alps was open with predominantly herbaceous plants (Vescovi 2007, Andrič 2009). These palaeoenvironmental conditions also had a significant impact on the formation of the lateglacial glaciers in the Julian Alps.

\subsection{Research area}

This paper presents the continuation of an essay on the Lateglacial in the northern valleys of the Italian Julian Alps (Tintor 2005) and is based on a very detailed glacial-morphological treatise on the catchment of the Fella (Desio 1927).

The research area is framed by the western Val Canale from Ugovizza to Pontebba where it turns south, runs through the Canal del Ferro, bends westward close to Chiusaforte

and reaches the Resia valley at Resiutta. East of Passo di Predil $(1156 \mathrm{~m})$ the article also dealt with the $15 \mathrm{~km}$ long Koritnica valley which belongs to Slovenia and runs into the Soča valley in the Bovec basin (figure 1). The research area comprises about $360 \mathrm{~km}^{2}$.

The Val Canale lies at an altitude of $770 \mathrm{~m}$ in Ugovizza, however at only $568 \mathrm{~m}$ in Pontebba and just $315 \mathrm{~m}$ in Resiutta. The Dolina Koritnica reaches only $430 \mathrm{~m}$ near Bovec; this expresses how low the local base of erosion is in the western and and southern valleys of the Julian Alps. The altitude difference is often higher than $2000 \mathrm{~m}$ at a horizontal distance of only $5 \mathrm{~km}$ : Montasio is $2200 \mathrm{~m}$ above the Dogna and Raccolana valleys, Canìn is $2090 \mathrm{~m}$ higher than the Resia valley and Mangart is $2040 \mathrm{~m}$ higher than the Koritniška valley (Tintor 1993). This precipitous relief together with the enormous precipitation cause extraordinarily high morphodynamics with landslides, mudstreams, debris amount and a strong notching and ramification into tributaries, especially in the western valleys. These facts show clearly that large parts of the valleys do not or cannot contain lateglacial moraines any longer as they were eroded. 
The recent conditions of precipitation - they may have been very similar in the Lateglacial - should be dealt with in greater detail: in the Resia valley on average $2700-3000 \mathrm{~mm}$ are recorded annually and in Bovec $2840 \mathrm{~mm}$ (1951-1980). This precipitation situation may be compared to an extra-alpine and Mediterranean region, the Durmitor area in Montenegro where the calculated precipitation on the highest parts amounts to about $2600 \mathrm{~mm}$ (Djurović, 2009; 2012). Very favourable for glaciation is the annual course of precipitation influenced by the Mediterranean Sea with the main peak in autumn and the secondary one in spring; it can be assumed that in the Lateglacial most of the precipitation fell in the form of snow. On Sella Nevea two metres of snow are not unusual in wet winters. Finally it must be emphasized that particularly in the lee of W-E directed ridges and crests most of the snow was deposited; this can be considered the reason that today two small glaciers still exist in a low position at the foot of the north faces of Canin and Montasio.

\section{The Lateglacial in the individual valleys}

\subsection{Dogna valley}

Because of the deeply notched and narrow valley bottom terminal moraines are missing entirely in the Dogna valley; they must have been eroded rapidly, while many lateral moraines were found. In the lower section

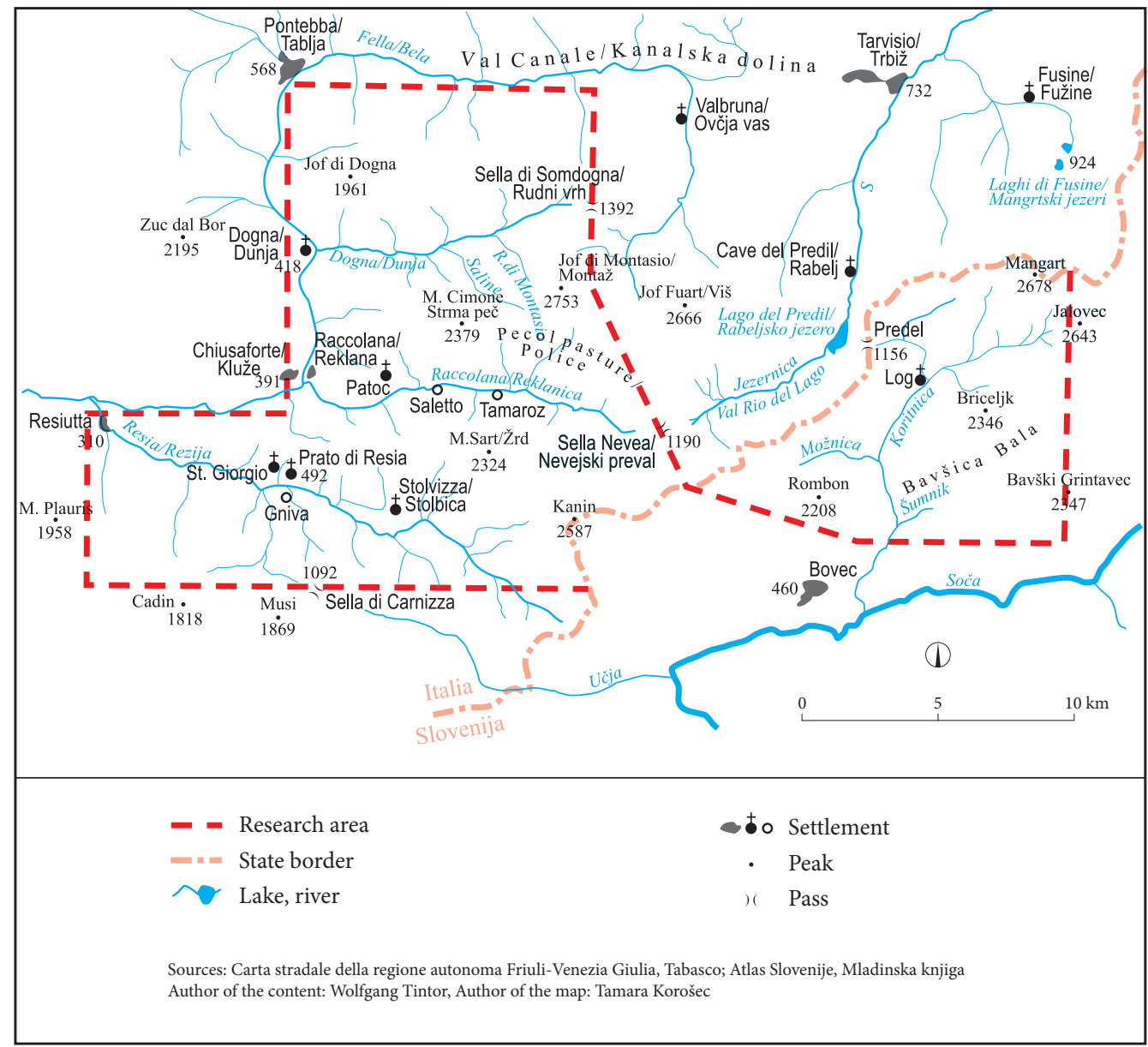

Figure 1: Research area, its surroundings and sites of lateglacial moraines. 
on the still more easily accessible north side four smaller ridges were found of which two at a time correlate in their altitude ( $770 \mathrm{~m}$ below Chiout Zucuin and $730 \mathrm{~m}$ a bit W of Chiout di Gus; $950 \mathrm{~m}$ on the slope Culas above Chiout Zucuin and $920 \mathrm{~m}$ at the pasture Tassót). The ice thickness can thus be determined to $410 \mathrm{~m}$ at the utmost for the upper moraines and to $220 \mathrm{~m}$ for the lower ones (probably Bühl stage).

Regrettably no certain indications could be found for the Steinach stadial in the entire valley, whereas the Gschnitz stage has left very clear marks, particularly on the southern valley flank.

If you follow the marked path no. 640 well-rounded triassic boulders can be found close to house ruins on the former pasture Costa di Goliz $(650 \mathrm{~m})$; a near-terminus lateral moraine can be seen up to $720 \mathrm{~m}$, above which erratics are found up to $800 \mathrm{~m}$.

Beyond the hard passable Sfonderat gorge after another brook notch you get to the rock ledge reforested pasture Granvalt where at $660 \mathrm{~m}$ there are situated two well-formed lateral moraines (Desio 1927). Here the valley bottom consists of yellow marl limestones of the Raibl strata; so the numerous triassic boulders on the opposite valley side stand out against those particularly well. At $630 \mathrm{~m}$ just below the road there is the largest erratic block consisting of light Dachstein limestone showing that presumably a very steep Gschnitz glacier fed primarily by avalanches flowed a short distance out of the Sfonderat gorge into the Dogna valley. Very similar conditions will have prevailed in the adjacent Rondolon gorge where however no moraines could be found, just some erratics here and there. The snowline calculated just overviewingly

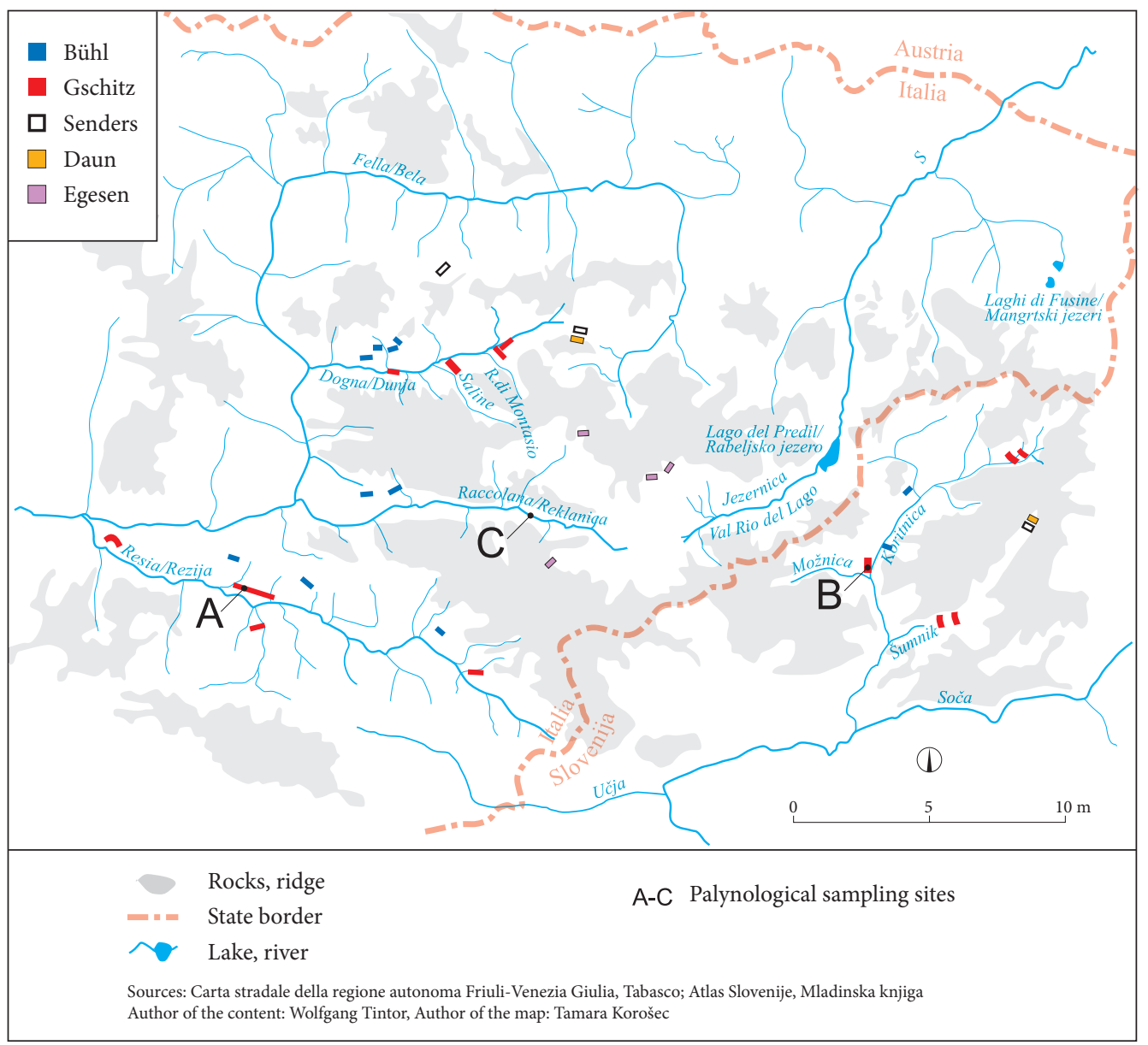

Figure 2: Presumable stadials of the moraines and palynological sampling sites 


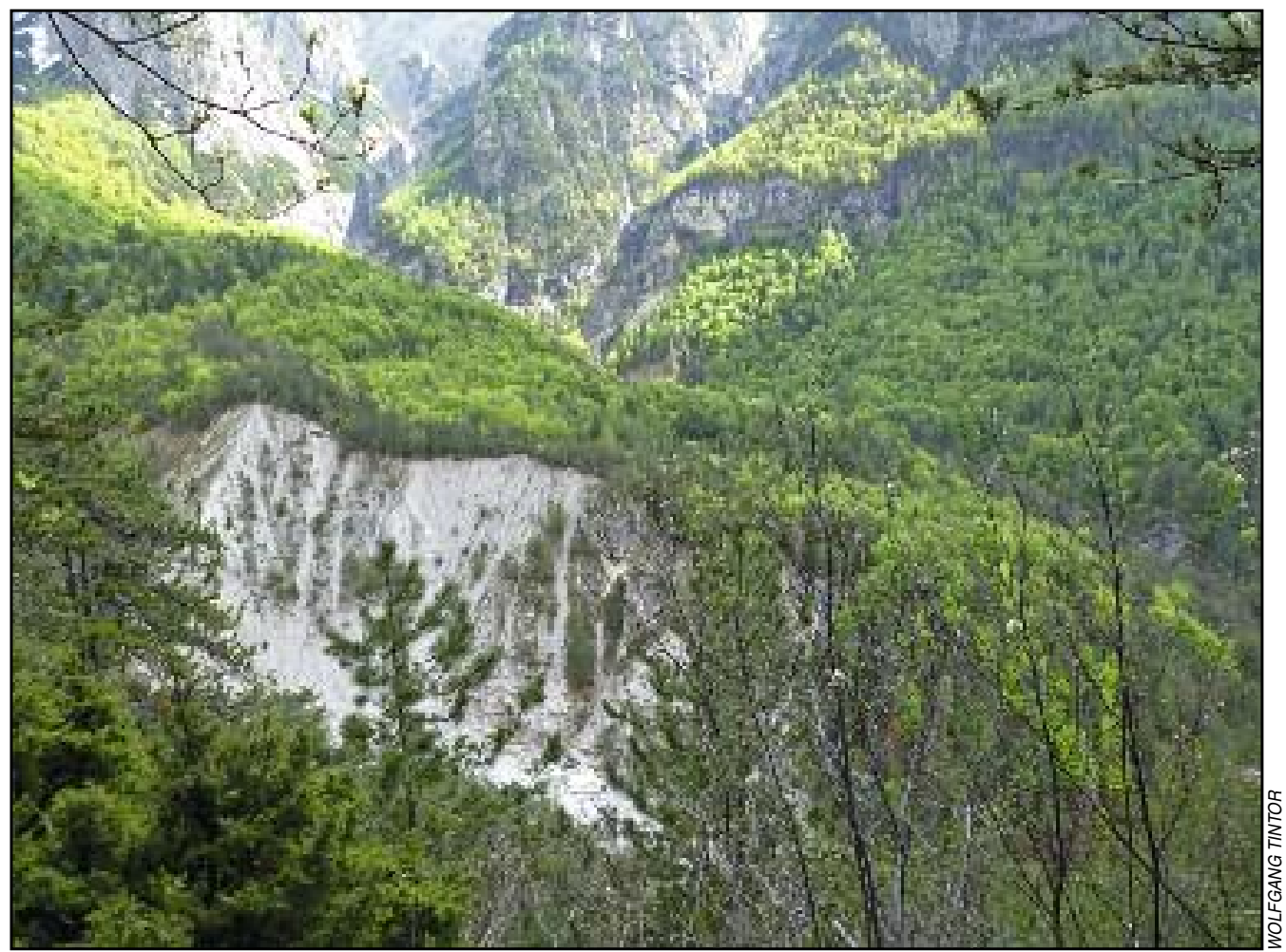

Figure 3: Gschnitz moraine cut by the Dogna stream toward Clapadorie gorge; position Dogna Road.

for both of the gorge glaciers would result in 1300-1400 m (method Höfer) which is low for the Gschnitz stadial and can only be explained with the particular topographical position.

The side gully of Rio Saline following in the east is the widest of all north facing gullies in the Dogna valley. Its Gschnitz glacier reached a length of $4.5 \mathrm{~km}$ and its near-terminus lateral moraines west of Colle Fratte are impressive accumulations up to a height of $20 \mathrm{~m}$ (Desio 1927). The snowline determined with $1480 \mathrm{~m}$ corresponds fairly exactly to that for the somewhat longer Gschnitz glacier in the Val di Rio Freddo (Tintor 2005).

The uppermost and very last side gorge in the Dogna valley is the already mentioned Clapadorie. Its glacier pushed up two marked near-terminus lateral moraines at its right side. The snowline of this glacier fed exclusively by drifted snow and avalanches was calculated for $1520 \mathrm{~m}$ (figure 4).

On the Somdogna pass there is a wide and $500 \mathrm{~m}$ long ridge on its southernn side showing a small pond at its inner side (Il Laghetto, $1442 \mathrm{~m}$ ). Most probably in the Senders stage a largely debris-covered glacier must have come down there into the soft marl limestones of the Raibl layers at the pass. The snowline of the $900 \mathrm{~m}$ long cirque glacier was at $1630 \mathrm{~m}$, which is strikingly low, but that should be caused by the north-east exposure and the steep relief of the lower glacier half.

At the lower end of the small cirque of Jof di Somdogna you find a terminal moraine $(1620 \mathrm{~m})$ whose $500 \mathrm{~m}$ long glacier was very shallow in its snout area and may be assigned to the Daun stadial.

\subsection{Raccolana valley}

In this narrow mountain valley with frequently vertical rock walls there are only few lateglacial moraines; near its lower end in a flat area of Stavolo Bilizzis $(558 \mathrm{~m})$ many light, rounded triassic boulders can be 
Sources: Carta stradale della regione autonoma Friuli-Venezia Giulia, Tabasco; Atlas Slovenije, Mladinska knjiga

Author of the content: Wolfgang Tintor, Author of the map: Tamara Korošec

Gschnitz moraine

- Gschnitz moraine uncertain

- $25 \mathrm{~m}$ - contour line

Stream

立三. Bog

Road

$\stackrel{200}{0} \quad 400 \mathrm{~m}$

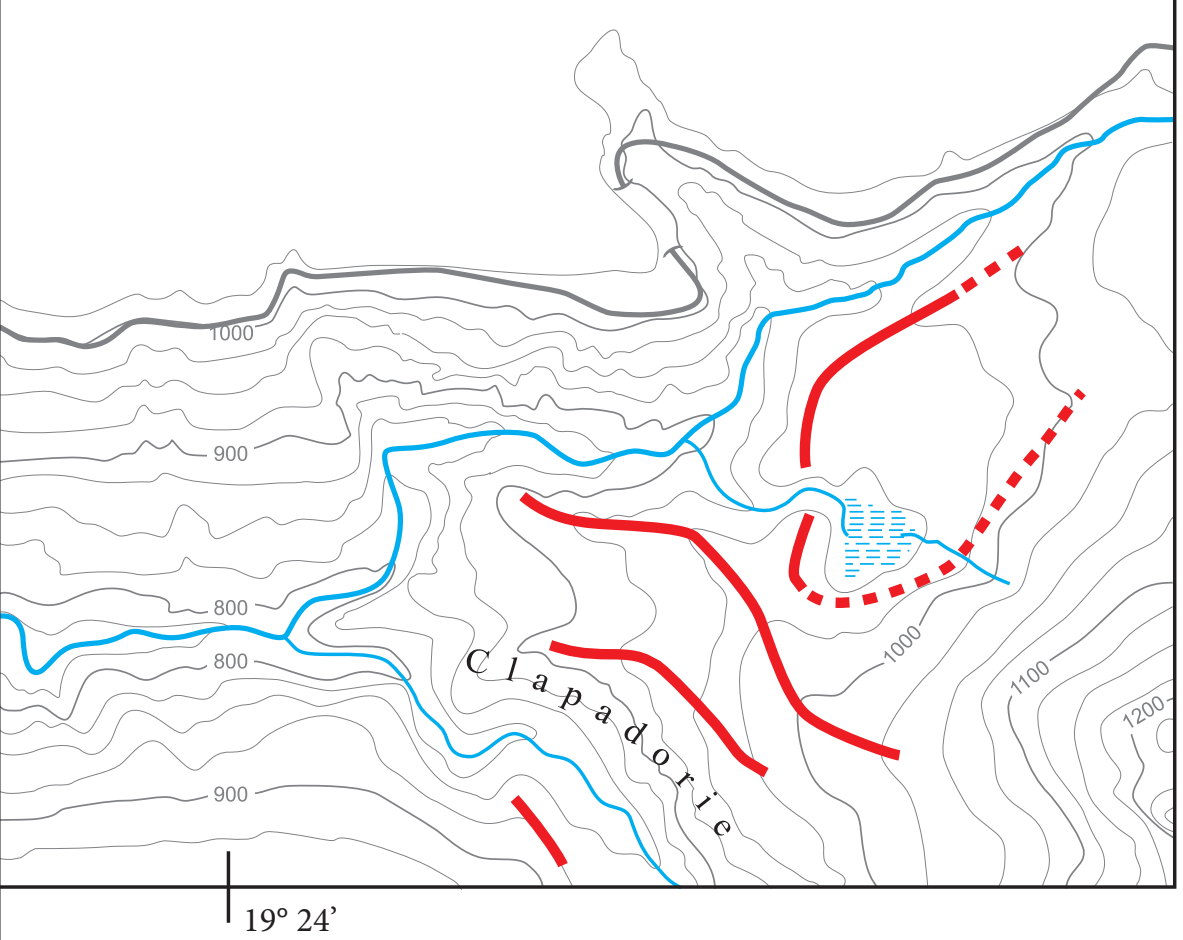

Figure 4: Gschnitz moraines in the upper Dogna valley.

found; most probably they have to be assigned to the Bühl stadial as they belong to a small lateral ridge high above the valley bottom. In this phase the Raccolana glacier must have been $140 \mathrm{~m}$ thick.

The impressive Patòc moraines $(785 \mathrm{~m})$ on the sunny side above Chiout Michel are Bühl-lateral moraines indicating a glacier with a thickness of $300 \mathrm{~m}$. From here a small and shallow branch (20-25 $\mathrm{m}$ thick) flowed down the Patòc valley.

Like in the Dogna valley Steinach moraines are missing completely here as well; it can be concluded that in this stadial most of the Raccolana valley was filled with ice. This also implies that the massive kame terraces in the valley must be of younger age.

$80 \mathrm{~m}$ above the valley floor (Plan Moras) a $2.5 \mathrm{~km}$ long gorge glacier flowing down the Sbrici ravine pushed up a near-terminus lateral moraine; due to its location at the confluence of a side gorge it must 
have been a Gschnitz glacier. The snowline calculated roughly resulted in $1250 \mathrm{~m}$ which is a very low value. The very steep and narrow gorge glaciers in this valley had all in common that they lay far below the climatic snowline even at that time.

The two kame terraces following up the valley, at Tamaroz and $\mathrm{W}$ of it with flat areas in $600-620 \mathrm{~m}$ will have been dammed by a north-facing hanging glacier from Cresta Indrinizza and by a small S facing ice stream from Monte Cimone. From the very steep Vallone Blasic another glacier must have run down in the Gschnitz stadial. Today only some ice-abraded rock zones in the steep tributary give evidence of it and also the fine sediments dammed at its lowest margin when the glacier blocked the valley bottom temporarily. The snowline of the $3 \mathrm{~km}$ long glacier will have been at an altitude of $1400 \mathrm{~m}$.

Up the valley on a hill similar to a ridge a sediment sample for a pollen analysis was collected and the results (table 1) showed that pollen grains are present in very low concentration, whereas the percentage of degraded pollen is high $(20 \%)$ suggesting a selective degradation of pollen grains. Of the preserved tree pollen birches, pines and spruces predominated; as in the vicinity of the digging zone there are many beeches and many roots in the uppermost layer of the soil there could have been a contamination with recent beech pollen in the sample (table 1). Even so doubts remain if this formation really is a moraine of the Gschnitz stadial. It could also be an atypical postglacial debris flow and is therefore not contained in figure 2, but the sites of the samples are marked with A-C. In any case the glacier belonging to it would have been $4 \mathrm{~km}$ long down from Sella Nevea whereas the main glacier flowing NE into Valle Rio del Lago still reached a length of $8.5 \mathrm{~km}$ in that stadial.

During a hiking tour on the $\mathrm{N}$ declivity of Canìn a small lateral moraine was found in Foran dal Muss at $1850 \mathrm{~m}$; due to its high altitude it may be assigned to the Egesen stadial. Another one was found at the turn-off of the track to Sella Blasic $(1950 \mathrm{~m})$. On the sunny Montasio side a terminal moraine could be detected at the lower end of the small Palone cirque; in its W part $(2090 \mathrm{~m})$ it is already covered by

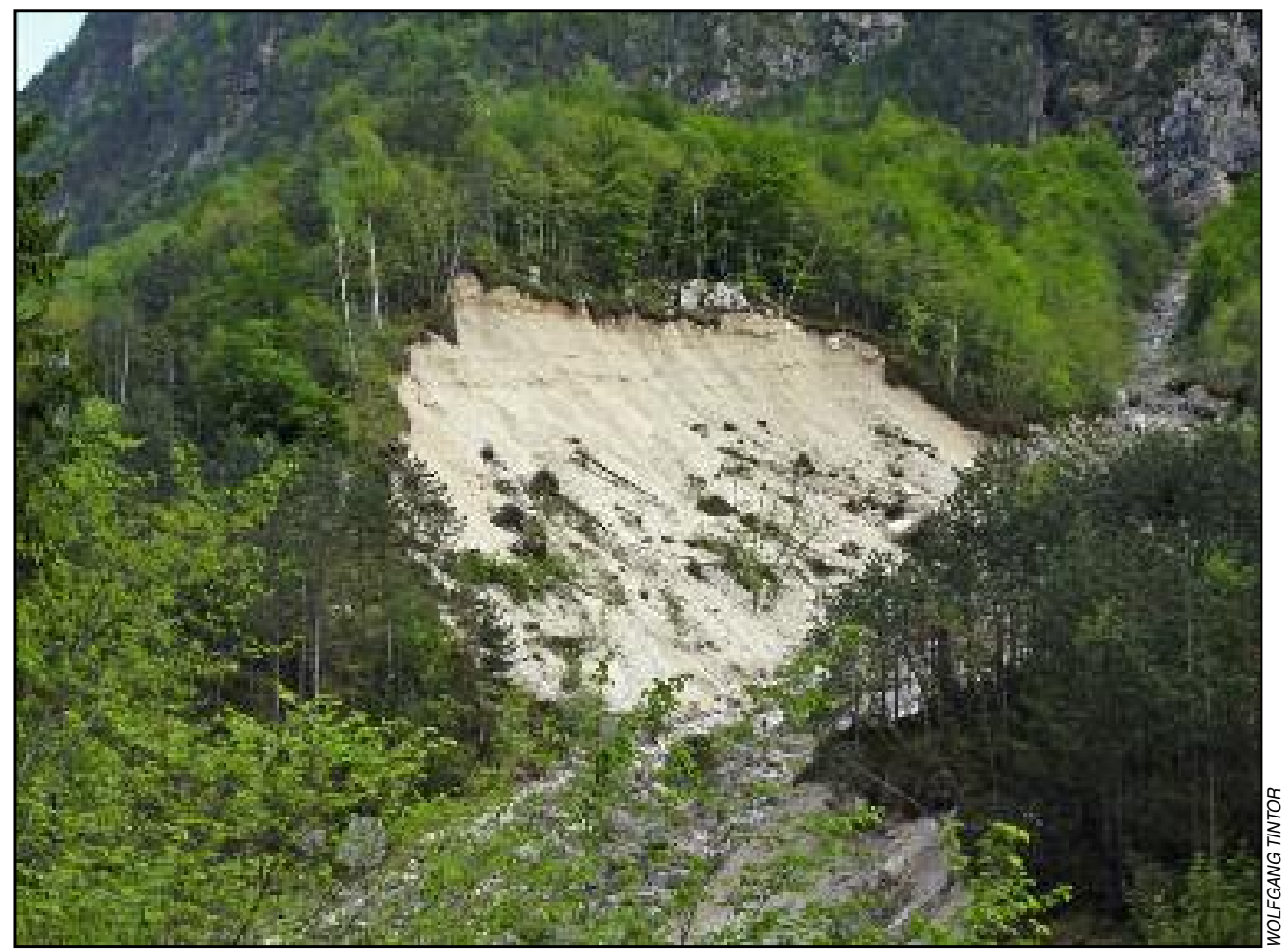

Figure 5: Fine sediments of a kame terrace east of Vallone Blasic; position Raccolana road. 
Table 1: The results of pollen analyses are presented as the number of pollen grains counted in each sample. In brackets the percentage of each pollen type was calculated on the basis of pollen sum of all taxa (without degraded pollen); see figure 2 for the position of the study sites.

\begin{tabular}{lccc}
\hline & Val Resia San Giorgio & Dolina Koritnica Možnica & Val Raccolana \\
& $460 \mathrm{~m}-\mathrm{A}$ & $530 \mathrm{~m}-\mathrm{B}$ & $655 \mathrm{~m}-\mathrm{C}$ \\
\hline Pinus (pine) & $145 \mathbf{( 3 5 . 9 \% )}$ & $40 \mathbf{( 2 0 . 3 \% )}$ & $6 \mathbf{( 8 . 6 \% )}$ \\
Picea (spruce) & $24 \mathbf{( 5 . 9 \% )}$ & $36 \mathbf{( 1 8 . 2 \% )}$ & $5(\mathbf{7 . 2 \% )}$ \\
Betula (birch) & $5 \mathbf{( 1 . 2 \% )}$ & $26 \mathbf{( 1 3 . 1 \% )}$ & $14 \mathbf{( 2 0 . 2 \% )}$ \\
Fagus (beech) & - & $4(2.0 \%)$ & $6(8.6 \%)$ \\
Alnus (alder) & $2(0.4 \%)$ & $1(0.5 \%)$ & $3(4.3 \%)$ \\
Corylus (hazel) & $10(2.4 \%)$ & $2(1.0 \%)$ & $6(8.6 \%)$ \\
Carpinus b. (hornbeam) & - & $1(0.5 \%)$ & $3(4.3 \%)$ \\
Salix (willow) & $1(0.2 \%)$ & - & - \\
Fraxinus 0. (ash) & - & - & $1(1.4 \%)$ \\
Poaceae (grass) & $8(1.9 \%)$ & $11(5.5 \%)$ & $9(13.0 \%)$ \\
Cyperaceae (sedge) & $11(2.7 \%)$ & $2(2.0 \%)$ & - \\
Chenopodiaceae (goosefoot) & - & $1(0.5 \%)$ & - \\
Compositae lig. (dandelion family) & $22(5.4 \%)$ & $23(11.6 \%)$ & $7(10.1 \%)$ \\
Filicales (monolete fern spores) & $171(42.4 \%)$ & $22(11.1 \%)$ & $9(13.0 \%)$ \\
Trilete spores (trilete fern spores) & $3(0.7 \%)$ & $23(11.6 \%)$ & - \\
Selaginella (clubmoss) & $1(0.2 \%)$ & $2(1.0 \%)$ & - \\
Thelypteris pal. (marsh fern) & - & $2(1.0 \%)$ & - \\
Indet. degraded (indetermined, & $16(3.9 \%)$ & $16(8.1 \%)$ & $14(20.2 \%)$ \\
degraded pollen) & 403 & 197 & 69 \\
Pollen sum & 6378 & 1109 & 406 \\
pollen concentration & & & \\
no. of grains/1 cm & & & \\
\hline
\end{tabular}

a recent debris slope, however towards $\mathrm{E}$ it is well marked and climbs up to $2125 \mathrm{~m}$ there. The little glacier will have occupied an area of $0.95 \mathrm{~km}^{2}$; together with the glaciated flanks at the foot of Modeon del Montasio it amounted to $1.5 \mathrm{~km}^{2}$.

In the spacious Cregnedul cirque a distinct terminal moraine of the Egesen stadial $(2030 \mathrm{~m})$ could be discovered; the glacier belonging to it had an area of $1.2 \mathrm{~km}^{2}$.

Following to $\mathrm{E}$ at the foot of Forcella Lavinal dell' Orso there is a striking terminal moraine at an altitude of 1990-2030 m; its Egesen glacier facing E amounted to $0.94 \mathrm{~km}^{2}$ and has also to be attributed to the catchment of Valle Rio del Lago.

Interestingly the terminal moraines of the same stadial in the region of Mt. Durmitor (Montenegro) are also situated at an altitude of ca. $2000 \mathrm{~m}$, some in the west even at $1800 \mathrm{~m}$ (Djurović 2009).

\subsection{Resia valley}

The southernmost of the three valleys is at the same time the lowest one; even so the valley was considerably glaciated in the Lateglacial because of the excessively high precipitation.

At Stavoli Ruschis 10-20 m high lateral moraines were discovered (crest height $697 \mathrm{~m}$ ) which can be assigned to the Bühl stadial with a high degree of certainty; at that phase the Resia glacier was still $330 \mathrm{~m}$ thick there. Another Bühl moraine was found E of Prato di Resia at the ruins of the pasture Bükvica $(705 \mathrm{~m})$; here, too the glacier was about $300 \mathrm{~m}$ thick. Two km east of Stolvizza some small moraines were discovered of which the corresponding ice thickness must also have amounted to $300 \mathrm{~m}$ and possibly $390 \mathrm{~m}$ for an older Bühl phase.

The moraine complex immediately $\mathrm{E}$ of the Calvary of Resiutta is bent convexly, about $400 \mathrm{~m}$ long, reaches $402 \mathrm{~m}$ in its highest point and must have been pushed up by a $4.5 \mathrm{~km}$ long glacier from the tributaries of Rio Resartico and Rio Serai. There a snowline of only $1070 \mathrm{~m}$ can be assumed. Apart from the very high quantities of snow again the great inclination, the north exposure, the narrow gullies and the slopes towering highly and steeply to east which counteract the intensive solar radiation, can be seen as supportive to glaciation. Besides the ridge from Monte Plauris to the Cime del Monte Musi as well as the valleys south 
and north of it still receive the highest annual precipitation of the Alps (Musi/Muzci $3313 \mathrm{~mm}$, Coritis $2939 \mathrm{~mm}$ ). This can also be assumed for the lateglacial climate in this region (Tintor 1993).

Only $4.5 \mathrm{~km}$ upstream and $50-80 \mathrm{~m}$ higher the largest moraines of this study area can be found: the $3.5 \mathrm{~km}$ long, mighty and blocky terminal moraines $(440-465 \mathrm{~m})$ of San Giorgio were attributed partly to fluvioglacial processes (Desio 1927). They correlate with the near-terminus lateral moraines on the other side of the stream at Gniva which can be followed up to $570 \mathrm{~m}$. They were accumulated by a $5 \mathrm{~km}$ long tributary glacier from the Barmán valley in which you come across the next terminal ridges already after $2 \mathrm{~km}$. Most probably they represent the second phase typical for the Gschnitz stadial and are again blocky. The snowline of this impressive ice stream was situated at $1130 \mathrm{~m}$ which again was only possible due to the special factors mentioned above. From the San Giorgio moraine a sediment sample was taken for a pollen analysis: $35.9 \%$ were pine pollen, only $5.9 \%$ spruce, $1.2 \%$ birch, ca. $2.7 \%$ sedge, but also $42.4 \%$ monolete fern spores (Filicales, table 1). Although these results are well comparable with the pollen record of the Gschnitz moraine at the lower Fusine lake (Tintor 2005), they do not permit the authors a very detailed datation of the moraine. But together with the morphological diagnosis it should be sufficient to classify both situations to the Gschnitz stadial.

In the upper valley section notching in side gullies and small ravines increases sharply, frequently you come across kame terraces, of which one of the largest is that of Huda Raven, southeast of the confluence of Rio Ronch; at its southeastern side $(564 \mathrm{~m})$ it is incised by Rio Secco and exposed in several decametres, in which you can observe an alternating deposition of coarse material and fine sediments (figure 6): The kame terrace is 50-60 m thick and was formed supposedly in the Gschnitz stadial at the margin of a glacier which flowed 4.5-5 km long from the $\mathrm{S}$ and $\mathrm{W}$ facing flanks of Picco di Grubia, Picco di Carnizza and Canìn. Its snowline must have been in 1430-1450 $\mathrm{m}$ which in view of the high precipitation at the Kanin/Canìn ridge is not so low.

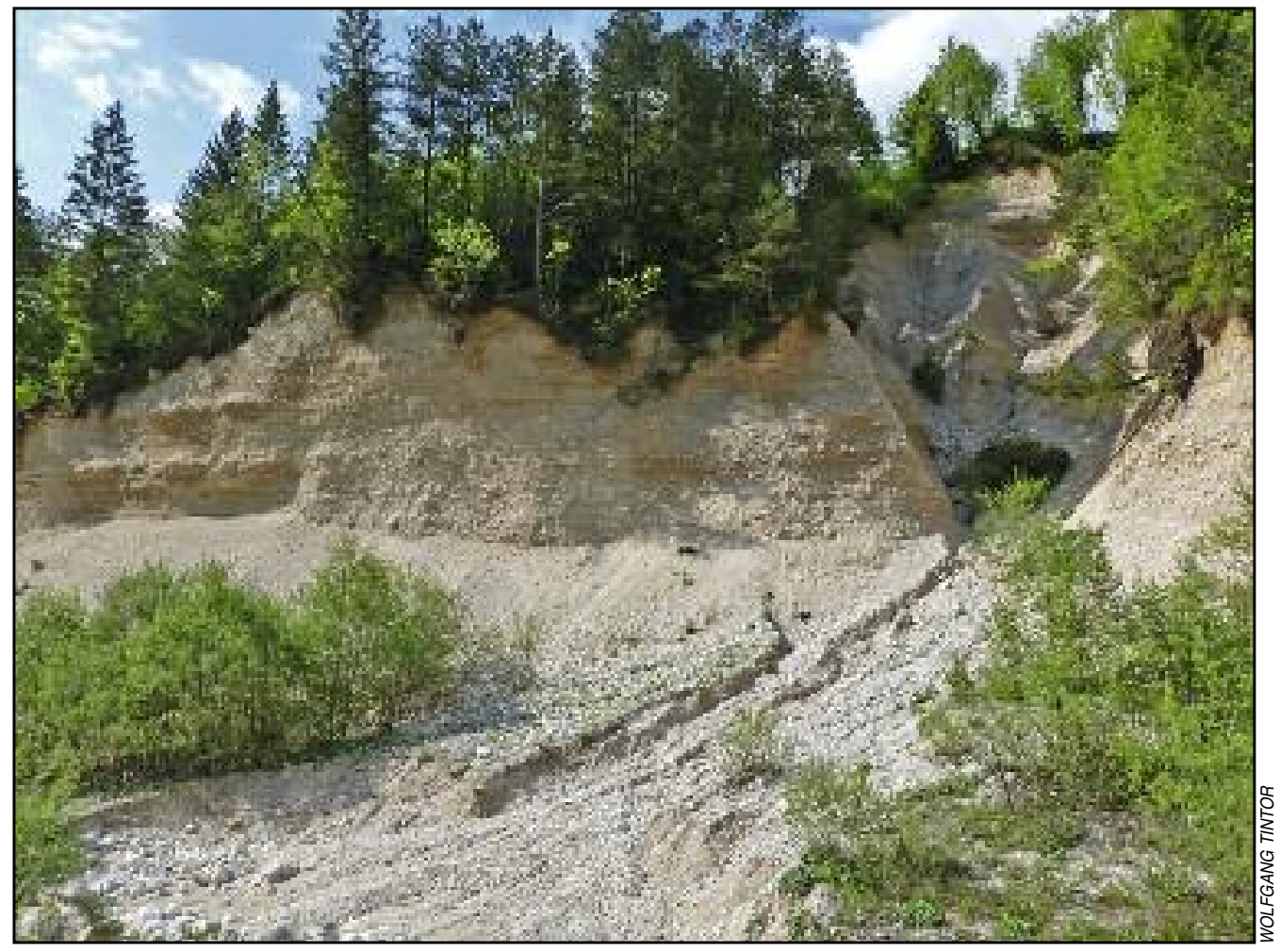

Figure 6: Up to $60 \mathrm{~m}$ high and $400 \mathrm{~m}$ long opening with sand and gravel of the kame terrace Huda Raven in the upper Resia valley; position Rio Secco. 


\subsection{Koritnica valley and tributaries}

The Koritnica valley shows a well-formed lateral moraine $(720 \mathrm{~m})$ on its western side immediately above the main village Gorenji Log pod Mangartom; it can be assigned to the Bühl stadial due to its altitude above the valley bottom. The glacier will have had a thickness of ca. $80 \mathrm{~m}$ in this part of the valley.

Šifrer and Kunaver (1978) mentioned six different end moraines only for Loška Koritnica which could not be verified. In the upper part of Koritnica two unambiguous and blocky glacial deposits were found: the lower one is situated in an altitude of $860-865 \mathrm{~m}$ close to the abandoned farm Ganza and the upper, more marked one in $940-950 \mathrm{~m}$. These should be the two phases of the Gschnitz stadial, but interestingly the glacier was hardly more than $3 \mathrm{~km}$ long here and ended fairly high. Accordingly high also the snowline of $1580 \mathrm{~m}-$ at an assumed mean altitude of the ridges framing the glacier with $2300 \mathrm{~m}$. The uppermost valley is exposed to the sun and furthermore the precipitation in the Lateglacial must have decreased rapidly from the outward ranges in the south toward north similar to the present time which was also decisive here (Tintor 1993).

The $5 \mathrm{~km}$ long, deeply notched side valley of Možnica is terminated at its southern side by the ridge from the Confin peak to Rombon; at the lower end of the valley there is a mighty, wide and 60-70 m high terminal moraine (max. $590 \mathrm{~m}$ ) which the stream cuts through meanderingly in a narrow gorge. On both sides two near-terminus lateral moraines run down steeply implying that the glacier in between was still $550 \mathrm{~m}$ wide and could have dammed the Koritnica river at least in the first Gschnitz phase (figure 7). A lateral moraine was found at $800 \mathrm{~m}$ by geologists who also reconstructed the glaciers of the Koritnica and Soča valley for a stadial not mentioned by modelling (Bavec 2004); so their climatic snowline calculated for the whole area bears no relation to the orographical snowline of our local glaciers.

A sample taken from the lower part of the moraine $(530 \mathrm{~m})$ produced a meaningful result with a high percentage of tree pollen (table 1); the pollen record itself allowed only a wider (presumably Lateglacial)

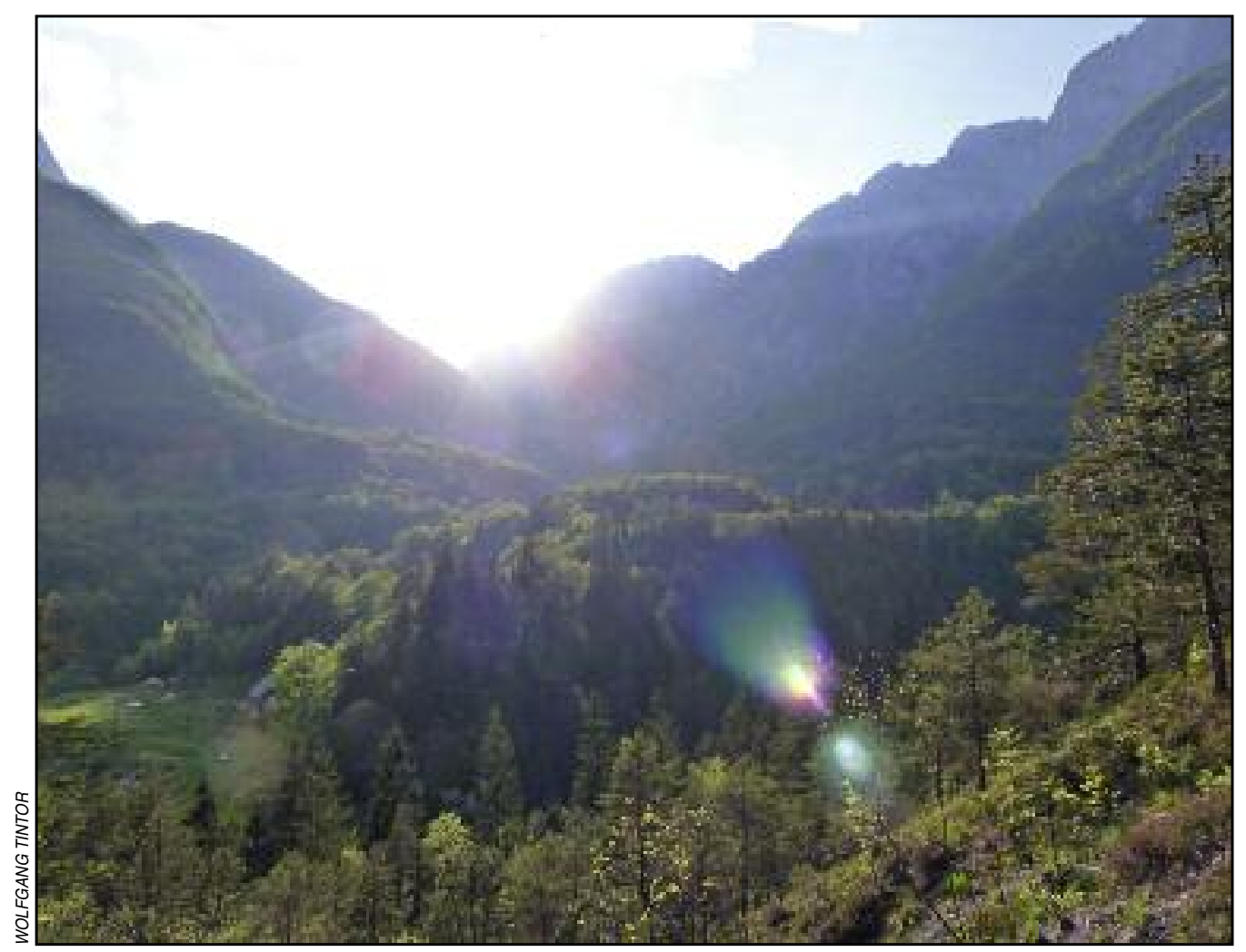

Figure 7: Moraine complex (centre and lower half of the picture) at the confluence of Možnica into the Koritnica valley. 
temporal determination but the following additional factors also speak in favour of the Gschnitz stage in spite of the low location: the strong shading of the lateglacial glacier by the Rombon ridge in the south, the maximum zone of precipitation on this very ridge and connected with that the high snow accumulation in the immediate leeward side to the $\mathrm{N}$ of it, the special height of the moraine itself as well as the lack of other moraines in the more spacious area between 800 and $900 \mathrm{~m}$ in which for example in the northern valleys of the Julian Alps Gschnitz moraines are situated in large numbers. The snowline for the Možnica glacier amounted to a rather low value of $1250 \mathrm{~m}$.

The morphological map of Šifrer and Kunaver (1978) and a later paper (Kunaver 1990) describe six different end moraines for Bavšica and the Bala valley which could not be verified. The lowest, blocky terminal ridge is at $700 \mathrm{~m} ; 500 \mathrm{~m}$ up the valley you discover the next end moraine (figure 2). The glacier flowing down the Bala valley to Bavšica was $6.5 \mathrm{~km}$ long, a second southern tributary ice stream from Bavški Grintavec had a length of $3.5 \mathrm{~km}$ (table 2). The mean altitude of the peaks and ridges framing the lateglacial ice streams can be assumed with $2200 \mathrm{~m}$ here which means a snowline of $1450 \mathrm{~m}$. Kunaver (1990) assumes a Bühl stadial for these frontal moraines; however, they are too well preserved, arranged in two phases immediately behind each other and moreover, located in a tributary, not in the main valley.

In the area of Planina Bala alp just a valley step with debris slopes could be found but by no means an accumulation of glacial deposits. Only at an altitude of $1400 \mathrm{~m}$ you come across a small ridge which is a debris-rich accumulation, possibly belonging to the Senders stage; the glacier of this stadial was just $2 \mathrm{~km}$ long and its snowline was thus situated at $1800 \mathrm{~m}$. In a horizontal distance of about $700 \mathrm{~m}$ and at an altitude of 1560-1600 m you find another glacial proof which was pushed up by a small cirque glacier with a length of about $1.3 \mathrm{~km}$ and presumably it can be assigned to the Daun stadial.

Table 2: Front altitude (in $\mathrm{m}$ ) and length (in $\mathrm{km}$ ) of glaciers of the presumable Gschnitz stadial in the individual valleys.

\begin{tabular}{|c|c|c|c|c|}
\hline & Dogna & Raccolana & Resia & Koritnica \\
\hline Sfonderat & $(600 / 3,0)$ & & & \\
\hline Saline & $(750 / 4,5)$ & & & \\
\hline Clapadorie & $(830 / 3,5)$ & & & \\
\hline Somdogna & $950 / 2,5$ & & & \\
\hline Sbrici & & $(500 / 2,5)$ & & \\
\hline Blasic & & $(560 / 3,5)$ & & \\
\hline Monte Plauris & & & $400 / 4,5$ & \\
\hline Barmán & & & $440 / 5,0$ & \\
\hline Ronch & & & $(560 / 4,5)$ & \\
\hline Koritnica & & & & $860 / 3,0$ \\
\hline Možnica & & & & $520 / 5,0$ \\
\hline Bavšica/Bala & & & & $680 / 6,5$ \\
\hline
\end{tabular}

( ) - values $=$ estimated, without terminal moraines

\section{Conclusions}

All glaciers of the presumable Gschnitz stadial mentioned in this paper belonged without exception to the avalanche basin type without an actual accumulation area. All glaciers were strongly subordinate to the relief and were covered highly with debris, particularly the one streaming down from the Barmán valley, a north-facing tributary of the Resia valley and the Možnica glacier whose terminal moraines are exceedingly mighty.

Of the twelve lateglacial glaciers listed up in table 2 seven were north- or north-west-facing, three directed to southwest and one each was east- and south-southeast-facing. The lowest one was that ice stream flowing down from Monte Plauris to the lowest part of the Resia valley ( $400 \mathrm{~m}$ altitude of the front moraine), the highest one the small Somdogna glacier (figure 4), where it is no coincidence that the first was situated leeward of the ridge with the highest precipitation at the southern verge of the Alps and the latter one in the northernmost and therefore drier valley. The southern periphery of the Julian Alps is still considered to be the wettest part of the Alps. As described in the preceding chapters most glaciers owed their low 
position also favourable topographical aspects like the present Montasio glacier, a narrow gorge glacier with its snout at $1880 \mathrm{~m}$; therefore their local orographical snowline was far below the climatic snowline.

The precipitation increasing to the $S$ margin of the mountains corresponds with the snowline decreasing from north to south; it amounted to an approximate altitude of $1500 \mathrm{~m}$ on average of three glaciers for the $\mathrm{N}$ valleys (Tintor 2005); in the Dogna valley the mean value was just $50 \mathrm{~m}$ lower followed by the only insignificantly more southern Koritnica valley with $1430 \mathrm{~m}$ on average. The snowline in the Raccolana valley may have been $1325 \mathrm{~m}$ on average of only two very steep gorge glaciers which means another lowering of more than $100 \mathrm{~m}$. Likewise in the Resia valley it must have been located another $110 \mathrm{~m}$ lower, that is at $1210 \mathrm{~m}$ on average. The straight line from the lateglacial front moraines of the $\mathrm{N}$ valley glaciers to those of the Resia valley amounts to just $15-19 \mathrm{~km}$; the precipitation averaged from four stations each increases, however by $1000 \mathrm{~mm}$ at this distance according to present conditions (Tintor 1993). Thus also in this mountain range the importance of the precipitation can be expressed as the crucial parameter for glaciation along with the temperature and the relief.

\section{Acknowledgements}

The authors would like to thank Prof. Giovanna Meneghel from the Dipartimento di Economia, Società e Territorio of the university of Udine for her assistance in finding the geological maps. Furthermore we thank Mag. Dr. Irena Mrak from the department of geography of the university of Ljubljana for the provision of two older papers on the Soča and the Koritnica valley. Besides the author is grateful to his friend Erich Wipfler for accompanying him to the Sfonderat gorge in the Dogna valley. For the graphic arrangement of the figures we are indebted to Mrs. Timea Marekova and Mrs. Tamara Korošec. We are also grateful to Dr. Miloš Bavec and an anonymous reviewer for their comments on the first draft of the paper.

\section{References}

Andrič, M., Massaferro, J., Eicher, U., Ammann, B., Leuenberger, M. C., Martinčičc, A., Marinova, E., Brancelj, A., 2009: A multi-proxy Late-glacial paleoenvironment record from Lake Bled, Slovenia. Hydrobiologia 631-1.

Assereto, R., Comizzoli, G., Passeri, L. D., 1964: Carta geologica 1:100 000 - Foglio 14A. Tarvisio Trieste. Bavec, M., Tulaczyk, S. M., Mahan, S. A., Stock, G. M., 2004: Late Quaternary glaciation of the Upper Soča River Region (Southern Julian Alps, NW Slovenia), Sedimentary Geology 165-3-4.

Bennet, K. D., Willis, K. J., 2002: Pollen. Tracking environmental changes using lake sediments 3. Dordrecht. Cobertaldo, D., Gortani, M., Selli, R., 1949: Carta geologica delle tre Venezie 1:100 000- Foglio 14, PontebbaTrieste.

Desio, A., 1927: L'evoluzione morfologica del bacino della Fella in Friuli. Atti della Società Italiana di Scienze Naturali e del Museo Civico di Storia Naturale di Milano 65-3-4.

Djurović, P., 2009: Reconstruction of the pleistocene glaciers of Mount Durmitor in Montenegro. Acta geographica Slovenica 49-2, Ljubljana. DOI: http://dx.doi.org/10.3986/AGS49202

Djurović, P. 2012: The Debeli Namet glacier (Durmitor, Montenegro) - from the second half of the 20th century to the present. Acta geographica Slovenica 52-2. DOI: http://dx.doi.org/10.3986/AGS52201

Dollinger, F., 1986: Überlegungen zur spätglazialen Vergletscherung des Höllengebirges/Nördliche Kalkalpen/Oberösterreich. Zeitschrift für Gletscherkunde und Glazialgeologie 22-2.

Fritz, A., Ucik, F. H. 2002: Eine unerwartete neue Deutung der Klima- und Vegetationsgeschichte des mitteleuropäischen Spätglazials. Mitteilungen der Österreichischen Geographischen Gesellschaft 144.

Fritz, A., Ucik, F. H. 2003: Das Gailtal (Kärnten) - Ein ostalpines Gehölzrefugium seit dem Ende des Würm-Hochglazials: Pollendiagramm Görtschach. Mitteilungen der Österreichischen Geographischen Gesellschaft 145.

Furrer, G., Burga, C., Gamper, M., Holzhauser, H. P., Maisch, M. 1987: Zur Gletscher-, Vegetations- und Klimageschichte der Schweiz seit der Späteiszeit. Geographica Helvetica 42.

Gams, I. 1992: Prispevek k mladokvavtarni geomorfologiji v zgornjesavski dolini. Geografski zbornik 32. Hambrey, M. Alean, J. 1992: Glaciers. Cambridge. 
Heuberger, H. 1968: Die Alpengletscher im Spät- und Postglazial. Quarternary science 19-1.DOI: http://dx.doi.org/ 10.3285/eg.19.1.24

Ivy-Ochs, S., Kerschner, H., Kubik, P. W., Schlüchter, C. 2006: Glacier response in the European Alps to Heinrich Event 1 cooling: the Gschnitz stadial. Journal of Quaternary science 21. DOI: http://dx.doi.org/ 10.1002 /jqs. 955

Kerschner, H., Berktold, E. 1981: Spätglaziale Gletscherstände und Schuttformen im Senderstal, Nördliche Stubaier Alpen, Tirol. Zeitschrift für Gletscherkunde und Glazialgeologie 17-2.

Kerschner, H. 1985: Quantitative palaeoclimatic inferences from lateglacial snowline, timberline and rock glacier data, Tyrolean Alps, Austria. tschrift für Gletscherkunde und Glazialgeologie 21.

Kerschner, H. 1986: Zum Sendersstadium im Spätglazial der nördlichen Stubaier Alpen, Tirol. Zeitschrift für geomorphologie 61 .

Kerschner, H. 1993: Späteiszeitliche Gletscherstände im südlichen Karwendel bei Innsbruck, Tirol. Innsbrucker Geographische Studien 20.

Kerschner, H., Ivy-Ochs, S., Schlüchter, C. 2002: Die Moräne von Trins im Gschnitztal. Geographiche Exkursionsführer Europaregion Tirol, Südtirol, Trentino 33-2.

Kugy, J. 1953: Die Julischen Alpen im Bilde. Graz.

Kunaver, J. 1975: H Geomorfološkemu razvoju Bovške kotline v Pleistocenu. Geografski vestnik 47. Ljubljana.

Kunaver, J. 1990: Poznoglacialne morene v najvišjih delih posoških Julijskih Alp in poskus njihove datacije. Zbornik referatov, 5.znanstveno posvetovanje geomorfologov Jugoslavije.

Lieb, G. K. 1987: Zur spätglazialen Gletscher- und Blockgletschergeschichte im Vergleich zwischen den Hohen und Niederen Tauern. Mitteilungen der Österreichischen Geographischen Gesellschaft 129.

Maisch, M., 1982: Zur Gletscher- und Klimageschichte des alpinen Spätglazials. Geographica Helvetica 37.

Melik, A. 1954: Slovenski alpski svet. Ljubljana.

Moore, P.D., Webb, J. A., Collinson, M. E., 1991: Pollen Analysis. Oxford.

Patzelt, G., 1975: Unterinntal - Zillertal - Pinzgau - Kitzbühel. Spät- und postglaziale Landschaftsentwicklung. Tirol, ein geographischer Exkursionsführer 2.

Penck, A., Brückner, E. 1909: Die Alpen im Eiszeitalter. Leipzig.

Reille, M., 1992: Pollen et Spores d'Europe et d'Afrique Du Nord. Laboratoire de Botanique Historique et Palynologie. Marseille.

Reille, M. 1995. Pollen et Spores d'Europe et d'Afrique Du Nord (Supplement). Laboratoire de Botanique Historique et Palynologie. Marseille.

Šifrer, M., Kunaver, J., 1978: Poglavitne značilnosti geomorfološkega razvoja zgornjega Posočja. Zgornje Posočje: zbornik 10. zborovanja slovenskih geografov. Ljubljana.

Stockmarr, J. 1971. Tablets with spores used in absolute pollen analysis. Pollen et spores 13. Paris.

Tintor, W. 1993: Die Kleingletscher der Julischen Alpen. Carinthia 103-183.

Tintor, W. 2002: Überlegungen zum Spätglazial zwischen Fusine und Rateče sowie im Mangarttal (Julische Alpen). Schriften der Geographie und Raumforschung 38.

Tintor, W. 2005: Zum Spätglazial in den nördlichen Tälern der italienischen Julischen Alpen. Carinthia 115-195.

Van Husen, D. 1977: Zur Fazies und Stratigraphie der jungpleistozänen Ablagerungen im Trauntal. Jahrbuch Geologische Bundesanstalt, 120/1.

Van Husen, D. 1988: Zur quartären Entwicklung in Kärnten. Kärnten - Naturwissenschaftlicher Verein Kärnten, Klagenfurt.

Van Husen, D. 2000: Geological Processes during the Quaternary. Mitteilungen der Österreichischen Geographischen Gesellschaft 92.

Vescovi, E., Ravazzi, C., Arpenti, E., Finsinger, W., Pini, R., Valsecchi, V., Wick, L.,

Ammann, B., Tinner, W. 2007: Interactions between climate and vegetation during the Lateglacial period as recorded by lake and mire sediment archives in Northern Italy and Southern Switzerland. Quaternary Science Reviews 26. DOI: http://dx.doi.org/10.1016/j.quascirev.2007.03.005

Winkler, A. 1931: Zur spät- und postglazialen Geschichte des Isonzotales (Südalpen). Zeitschrift für Gletscherkunde und Glazialgeologie 19. 